\title{
Students' Level of Satisfaction on the Program and Services Offered by the NEUST, San Isidro Campus
}

\author{
Engr. Ma. Teresita C. Vega, Ph.D.
}

Director, Nueva Ecija University of Science and Technology-San Isidro Campus

\begin{abstract}
This study described the level of satisfaction of 612 students on the different programs and services offered by the Nueva Ecija University of Science and Technology (NEUST), San Isidro Campus. The study found out that in general the students are very satisfied in the services offered by the campus particularly in their Guidance and Counselling, Career and Placement, Student Activities, Student Publication and Student Development, Scholarship and Financial Assistance, Sports Development, Culture, and the Arts, and Food Service. The finding indicates that the campus was able to comply with the enhanced guidelines and policies set by the Commission on Higher Education.
\end{abstract}

Keywords-Evaluation, guidance and counselling, level of satisfaction, programs, services.

\section{INTRODUCTION}

Education is said to be prestigious and perceived to be a fruitful investment that is rewarded in numerous ways [1]. It is normally presumed that formal schooling is an important contributor to the skills of an individual and to human capital (www.unesco.org).In today's competitive academic environment where parents and students have many options made available to them, factors that enable educational institutions to attract and retain students are being prioritized [2]. It has been mentioned by authors in [3] that competitive advantage in educational institutions can only be achieved by addressing the delivery of services to its customers, including the students as their main clientele.

The educational institutions are now battled with the purpose of providing quality services as this can be the primary reason for them to achieve sustainability. In the context of multicultural academic diversity that is now stimulated by g lobalization, it is necessary for all aspects of university life that includes student services, to meet these new challenges in today's era. Many aspects of student's life including academic, social or cultural level become more challenging to understand and manage with a population that finds itself in a state of continual growth and diversification [4]. The researchers in [5] emphasized that in order for the institution to become progressive of students' expectations, academic preferences and delivery perception about the educational environment should be kept by the higher authorities particularly the students who are at a higher academic level.

It is therefore important for universities to understand what the students valued most in their university experience [6], including their assessment towards the delivery of programs and services offered by their universities. This paper investigates the assessment of students on the delivery of the programs and services in Nueva Ecija University of Science and Technology (NEUST), San Isidro Campus: A basis for an assessment tool for student's programs and services in the Campus in particular and the NEUST in general. Nowadays, Higher Education Institutions are increasingly placing greater emphasis on meeting student's expectations and needs which makes this study well-timed. The significant findings of this study provided valuable information for administrators and curriculum planners to enhance policies [7] relating to services offered to college students of the said locale.

\section{OBJECTIVES OF THE STUDY}

This study determined the students' assessment on the delivery of programs and services in NEUST-San Isidro Campus. Specifically, it is based on the following objectives:

1. To determine the total number of students of NEUST San Isidro Campus categorized based on their college or department;

2. To describe the student's assessment on the delivery of programs and services in terms of:

2.1 Student Welfare Services; 


\subsubsection{Guidance and Counselling \\ Services; and,}

2.1.2 Career and Placement Services.

2.2 Student Development; and,

2.2.1 Student Activities; and,

2.2.2 Student Publication.

2.3 Institutional Development Programs
2.3.1 Scholarship
and Financial
Assistance;
2.3.2 Admission Services/Registrar's Services;

2.3.3 Student Development Programs and Services;

2.3.4 Sports Development Services;

2.3.5 Culture and the Arts Services; and,

2.3.6 Food Services.

3. To design a tool in assessing students' services and programs on the campus.

\section{METHODOLOGY}

This study utilized evaluation research which focuses on assessing the satisfaction of the students in the delivery of services and programs of NEUST, San Isidro Campus. According to [8], "evaluation research should enhance knowledge and decision making and lead to practical applications" [9].

The researcher targeted 612 student-respondents who were randomly selected from the enrollees of NEUST San Isidro Campus during the first semester of the A.Y. 2018-2019. The survey was conducted from August to November of 2018. It was designed to assess the 10 student's programs and services mandated by the Commission on Higher Education based on CMO No. 9, Series of 2013 [10]. Furthermore, in this study, the stratified sampling method was used to determine the number of participants in the study and the survey questionnaire was developed based on the mandates of CHED on the policies and guidelines on student affairs and services.

Scoring: Each response to every item was evaluated based on the following scale and verbal interpretations:

\section{Response}

\begin{tabular}{c|c|c|c}
\hline $\begin{array}{c}\text { Scale of } \\
\text { Values }\end{array}$ & $\begin{array}{c}\text { Scale of } \\
\text { Range }\end{array}$ & $\begin{array}{c}\text { Verbal } \\
\text { Description }\end{array}$ & Interpretation \\
\hline 5.00 & $4.21-5.00$ & Strongly Agree & The student is very satisfied with the delivery of services and programs \\
\hline 4.00 & $3.41-4.20$ & Agree & The student is satisfied with the delivery of services and programs \\
\hline 3.00 & $2.61-3.40$ & $\begin{array}{c}\text { Moderately } \\
\text { Agree }\end{array}$ & The student is moderately satisfied with the delivery of services and \\
& $1.81-2.60$ & $\begin{array}{c}\text { Slightly Agree } \\
\text { proms }\end{array}$ & The student is slightly dis satisfied on the delivery of services and \\
& & Disagree & The student is dis satisfied on the delivery of services and programs \\
\hline 1.00 & $1.00-1.80$ & . & \\
\hline
\end{tabular}

Statistical tools utilized in this study were frequency, percentage and weighted mean. 


\section{RESULTS AND DISCUSSION}

1.The total number of students of NEUST San Isidro Campus based on their department.

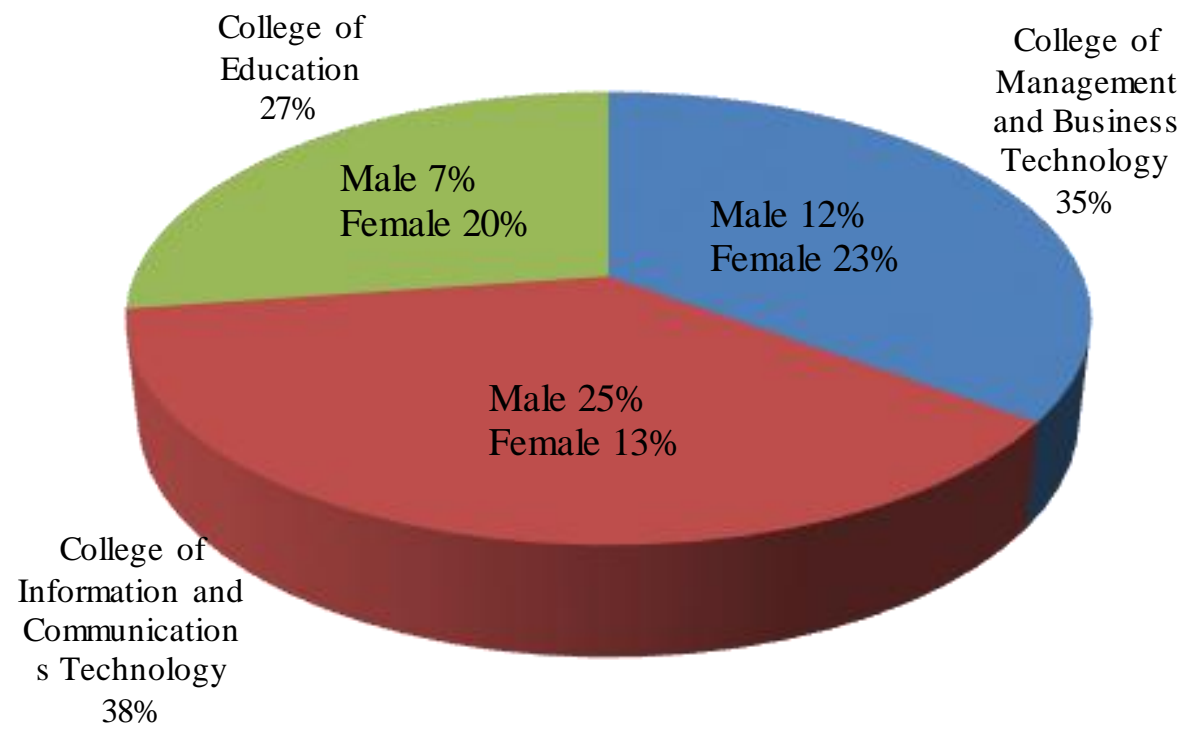

Fig.1: Distribution of Respondents per Department

The 612 student-respondents were randomly selected from the enrollees of the NEUST-San Isidro Campus during the first semester of the A.Y. 2018-2019. It has been noted from the data above that among the three departments, the College of Information and Communications Technology have the most number of enrollees. It also shows that the majority of the students in the CICT are male. Indeed, the computer industry has been traditionally viewed as a male-dominated profession [11].
Many students were interested in taking the said course because information technology is incredibly diverse which is not just confined in work related to fixing computers or laptops. This course allows an individual to have a career opportunity in a number of different directions which vary from a technical writing, web developing, information technology directorship, chief technology connected works and others [12].

\section{Assessment of the Respondents on Guidance and Counselling Services}

Table.1: Assessment of Guidance and Counselling Services

\begin{tabular}{|c|c|c|}
\hline Considerations & $\begin{array}{l}\text { Weighted } \\
\text { Mean }\end{array}$ & $\begin{array}{c}\text { Verbal } \\
\text { Description }\end{array}$ \\
\hline $\begin{array}{l}\text { 1. There is a Campus Guidance Office beside the Office of the Student Affairs } \\
\text { headed by a competent Guidance Coordinator. }\end{array}$ & 4.63 & Strongly Agree \\
\hline $\begin{array}{l}\text { 2. Guidance and counseling services are made available in the Campus where } \\
\text { one can immediately go to. }\end{array}$ & 4.48 & Strongly Agree \\
\hline $\begin{array}{l}\text { 3. There is a counseling room provided to ensure privacy and confidentially of } \\
\text { counseling sessions. }\end{array}$ & 4.42 & Strongly Agree \\
\hline 4. The guidance coordinator observes confidentiality of problems. & 4.43 & Strongly Agree \\
\hline $\begin{array}{l}\text { 5. The guidance office serves as the liais on I intervening problems among and } \\
\text { between students, faculty-students and other concerned academic concerns. }\end{array}$ & 4.37 & Strongly Agree \\
\hline Average Weighted Mean & 4.47 & Strongly Agree \\
\hline
\end{tabular}


According to [13], guidance is an imperative part of every child's development and education. Guidance and Counselling services are an integral part of every academic institution; it is part of the student services provided to assistthem in resolving and coping with conflicts arising from a changing society[14]. It is observed from the data above that the students are very satisfied with the delivery of services of the said office. This only implies that the campus is compliant with the guidelines and policies set by the Commission on Higher Education linked with the Guidance services as stipulated above.

\section{Assessment of the Respondents on Career and Placement Services}

Table.2: Assessment of Career and Placement Services

\begin{tabular}{rl|c|c}
\hline \multicolumn{1}{c|}{ Considerations } & Weighted Mean & Verbal Description \\
\hline $1 . \quad \begin{array}{l}\text { There is an Alumni office in the Campus that keeps records of } \\
\text { graduates for future references. }\end{array}$ & 4.51. & Strongly Agree \\
\hline 2. & $\begin{array}{l}\text { The Alumni office has a file of Tracer study on the } \\
\text { whereabouts of the graduates and is being monitored. }\end{array}$ & 4.33 & Strongly Agree \\
\hline $3 . \quad \begin{array}{l}\text { Informative materials are made available and are posted on } \\
\text { bulletin boards on job opportunities in skill development } \\
\text { programs. }\end{array}$ & 4.32 & Strongly Agree \\
\hline 4. & $\begin{array}{l}\text { Regular career and job placement services are available for the } \\
\text { students most especially for graduating students. }\end{array}$ & Strongly Agree \\
\hline 5. & $\begin{array}{l}\text { The Alumni office coordinates with the community, public } \\
\text { and private agencies, Alumni, for possible placements for } \\
\text { students. }\end{array}$ & 4.29 & \\
\hline Average Weighted Mean & $\mathbf{4 . 3 5}$ & Strongly Agree \\
\hline
\end{tabular}

The college career and placement services department is like a travel agency in this analogy and offers a variety of services to the student travellers [15]. The studentrespondents were very satisfied with the services of this office which means that graduates are given better opportunities after graduation due to the compliance of the university when it comes to their placement. It has been stated by [16] that upon the completion of the student's degree, if the students would not attain a higher level of education like Master's degree, they would rather pursue careers and that makes the services of this office essential.

\section{Assessment of the Respondents on Student Activities}

Table.3: Assessment of Student Activities

\begin{tabular}{rl|c|c}
\hline \multicolumn{1}{c|}{ Considerations } & Weighted Mean & Verbal Description \\
\hline $1 . \quad \begin{array}{l}\text { There is an office for students development programs and services known } \\
\text { as the OSOAD (office for student organization activities and development) } \\
\text { manned by a competent and committed head and adviser }\end{array}$ & 4.44 & Strongly Agree \\
\hline $2 . \quad \begin{array}{l}\text { The OSOAD helps and as sists the student-officer in the planning and } \\
\text { conduct of co-curricular activities. }\end{array}$ & 4.44 & Strongly Agree \\
\hline 3. & $\begin{array}{l}\text { There are guidelines being followed in choosing officers for political } \\
\text { student organizations as University Students Government- USG and the } \\
\text { different Campuses/Colleges' student council officers. }\end{array}$ & 4.33 & Strongly Agree \\
\hline 4. & & \\
$\begin{array}{l}\text { Applications forms for recognition and renewal of recognition for non- } \\
\text { political student organizations are readily available and accessible at the } \\
\text { OSOAD and CSC office. }\end{array}$ & 4.33 & Strongly Agree \\
\hline 5. $\begin{array}{l}\text { Every student's organization are guided by qualified and competent } \\
\text { faculty-advisers who served as their fathers/mothers during the conduct of } \\
\text { the plan activities such as leadership programs and other related student } \\
\text { activities. }\end{array}$ & 5.00 & Strongly Agree \\
\hline Average Weighted Mean & & Strongly Agree \\
\hline
\end{tabular}


Student's activities under student development programs and services delivered their services to the students in a very satisfactory level with a 4.51 average weighted mean. According to authors in [1], the satisfaction of the students on the services they received from the university which includes the office that caters students' activities plays a major role in determining the delivery of services of an educational system; they also revealed that the higher the level of satisfaction of the student-clienteles, the higher will be the level of students' groo ming their skill development, course knowledge and mentality.

\section{Assessment of the Respondents on Student Publication}

Table.4: Assessment on Student Publication

\begin{tabular}{rl|c|c}
\hline \multicolumn{1}{c|}{ Considerations } & Weighted Mean & Verbal Description \\
\hline 1. & $\begin{array}{l}\text { There is an office for Campus paper publication known as “The } \\
\text { Anihan manned by a competent and knowledgeable head and adviser" }\end{array}$ & 4.42 & Strongly Agree \\
\hline 2. & $\begin{array}{l}\text { The school publication place a liaison between the students and the } \\
\text { administration on issues relative to education and related concerns. }\end{array}$ & 4.27 & Strongly Agree \\
\hline 3. $\quad$ The publication issues The Anihan magazine's ones every semester. & 4.13 & Agree \\
\hline $4 . \quad \begin{array}{l}\text { The contents of publishing is sues are relevant to the students- } \\
\text { subscribers. }\end{array}$ & 4.23 & Strongly Agree \\
\hline 5. & $\begin{array}{l}\text { The publication solicits articles from the students and considers } \\
\text { suggestion and comments of students forpublication. }\end{array}$ & 4.21 & Strongly Agree \\
\hline Average Weighted Mean & $\mathbf{4 . 2 5}$ & Strongly Agree \\
\hline
\end{tabular}

It is observed from the data above that the campus managed to deliver the services concerning the student's publication very satisfactory with an average weighted mean of 4.25. The idea of establishing a student publication which can be in the form of print and non-print media of the university is supported by the Commission on Higher
Education as provided by R.A. No. 7079 otherwise known as, "Campus Journalism Act of 1991" [10]. The school publication is a significant avenue that is an outlet which intensively covers things that matter to both the studentjournalists and the stakeholders they cover [17].

\section{Assessment of the Respondents on Scholarship and Financial Assistance}

Table.5: Assessment of Scholarship and Financial Assistance

\begin{tabular}{rl|c|c}
\hline \multicolumn{1}{c|}{ Considerations } & Weighted Mean & Verbal Description \\
\hline 1. & $\begin{array}{l}\text { There is an office for a scholarship under the office of the student affairs } \\
\text { that caters the scholarship program of the Campus. }\end{array}$ & 4.57 & Strongly Agree \\
\hline 2. & $\begin{array}{l}\text { Scholarship brochures are made available at the center why the } \\
\text { dissemination of information and easy access on scholarship programs' } \\
\text { concerns, requirements, guidelines and the like. }\end{array}$ & 4.35 & Strongly Agree \\
\hline 3. & $\begin{array}{l}\text { Departments of Campus provided with clear application procedures in } \\
\text { the application of different scholarships and/or financial grants-in-aid } \\
\text { programs. }\end{array}$ & 4.27 & Strongly Agree \\
\hline $\begin{array}{l}\text { The scholarship center and gives prompt service to the applicants in } \\
\text { processing their papers. }\end{array}$ & 4.41 & Strongly Agree \\
\hline 5. & $\begin{array}{l}\text { The applicants undergo screening and are given enough time to process } \\
\text { their application. }\end{array}$ & 4.28 & Strongly Agree \\
\hline Average Weighted Mean & $\mathbf{4 . 3 8}$ & Strongly Agree \\
\hline
\end{tabular}

The data above revealed that the student-respondents were satisfied with the delivery of services related to scholarship and financial assistance of the campus with an average weighted mean of 4.38. In the Philippines, which is a developing country, there are many high school graduates who cannot be sent by their parents to school due to poverty. 
In this case, scholarships play an important role in making college for student-scholars more accessible and affordable, and paving the way for students to be successful in both their pursuit and completion of their degree[18]. Thus, the availability of scholarships and the services this office provides creates a strong foundation for supporting students in their schooling. Actually, in the study previously conducted by the researchers in [19], one of the factors being considered by the students in choosing their college is the scholarships and grants offered by the institution.

\section{Assessment of the Respondents on Admission Services/Registrar's Services}

Table.6: Assessment on Admission Services/Registrar's Services

\begin{tabular}{r|c|c}
\hline \multicolumn{1}{c|}{ Considerations } & Weighted Mean & Verbal Description \\
\hline 1. $\quad \begin{array}{l}\text { There is a registrar's office located at the Campus } \\
\text { where the enrolment procedure is carried out. }\end{array}$ & 4.33 & Strongly Agree \\
\hline 2. Student's grades are released on time. & 4.10 & Agree \\
\hline 3. There is a clear procedure on completion of grades. & 4.23 & Strongly Agree \\
\hline 4. Request for certification is acted upon promptly. & 4.15 & Agree \\
\hline 5. Credential evaluation is carried out promptly. & 4.17 & Agree \\
\hline Average Weighted Mean & $\mathbf{4 . 2 0}$ & Agree \\
\hline
\end{tabular}

The data above disclosed that the admission and registrar services in the campus are perceived to be satisfactory by the students in terms of their services delivery with an average weighted mean of 4.20. This result only shows that said office fully delivers the quality services demanded by the student-respondents which are linked with the accuracy and timeliness in the release of information and records from the Registrar's Office. According to [20], the role of the registrar in a school is no longer confined in mere record keeping. He emphasized that it has already evolved from keeping and safeguarding student records to data analysis and management relevant to school planning and decisionmaking. He also added other functions that range from troubleshooting to marketing of the school.

\section{Assessment of the Respondents on Student Development Programs and Services}

Table.7: Assessment of Student Development Programs and Services

\begin{tabular}{|c|c|c|}
\hline Considerations & Weighted Mean & Verbal Description \\
\hline $\begin{array}{l}\text { 1. There is an office for students development programs and services } \\
\text { known as the OSOAD (office for student organization activities and } \\
\text { development) manned by a competent and committed head and adviser }\end{array}$ & 4.44 & Strongly Agree \\
\hline $\begin{array}{l}\text { 2. The OSOAD helps and assists the student-officer in the planning and } \\
\text { conduct of co-curricular activities. }\end{array}$ & 4.44 & Strongly Agree \\
\hline $\begin{array}{l}\text { 4. Applications forms for recognition and renewal of recognition for non- } \\
\text { political student organizations are readily available and accessible at the } \\
\text { OSOAD and CSC office. }\end{array}$ & 4.33 & Strongly Agree \\
\hline $\begin{array}{l}\text { Average Weighted Mean } \\
\end{array}$ & 4.51 & Strongly Agree \\
\hline
\end{tabular}

When it comes to student development programs and services, the student-respondents divulged that they were very satisfied with the delivery of such services with an average weighted mean of 4.51 . This assessment only implies that the students are equipped with activities that meet their envisioned learning outcomes. Students perceived that the development programs of the campus are significant in their development and growth as an individual 
and as future professionals. They appreciated the accessibility and the guidance of the office to their different planned pieces of training and activities such as leadership pieces of training, team building, seminars, workshops, exhibits, quiz bees, paper presentations and many other extracurricular activities that are separated from their academic endeavors.

\section{Assessment of the Respondents on Sports Development Services}

Table.8: Assessment of Sports Development Services

\begin{tabular}{|c|c|c|}
\hline Considerations & Weighted Mean & Verbal Description \\
\hline 1. There is a schoolcanteen located at the Campus. & 4.32 & Strongly Agree \\
\hline $\begin{array}{l}\text { 2. There is a certificate to operate/sanitary permit } \\
\text { posted/dis played in a prominent area of the food outlet. }\end{array}$ & 4.36 & Strongly Agree \\
\hline $\begin{array}{l}\text { 3. There are enough food kiosks available which cater clean } \\
\text { and nutritious food within the Campus. }\end{array}$ & 4.36 & Strongly Agree \\
\hline 4. Foods are properly leveled as to its name and price. & 4.36 & Strongly Agree \\
\hline 5. Canteen personneland helpers observe proper grooming. & 4.40 & Strongly Agree \\
\hline Average Weighted Mean & 4.36 & Strongly Agree \\
\hline
\end{tabular}

The data above shows the assess ment of the students on the sports development services of the campus with an average weighted mean of 4.36 . The results have presented that the student-athletes were very satisfied with the services of such an office. As stated in[21], in the eyes of many students; sport, physical activity, and wellbeing plays an important part in university life. In fact, [22] cited that sports help an individual much more than in the physical aspects alone. He stressed out that it also builds our students' character, teaches and develops their strategic thinking, analytical thinking, leadership skills, goal setting, and risk-taking, just to name a few welfares.In the study conducted by the researchers in [23], it was found out that the participation of the students in school athletics has a positive significant relationship in their academic performance which only implies that sports development programs supporting school athletes must be given full attention to enhancing the wellness of the students.

\section{Assessment of the Respondents on Culture and the Arts Services}

Table.9: Assessment of Culture and the Arts Services

\begin{tabular}{c|c|c}
\hline \multicolumn{1}{c|}{ Considerations } & Weighted Mean & Verbal Description \\
\hline $\begin{array}{l}\text { 1. } \\
\text { There is an Office that manned and guide the Culture \& the } \\
\text { Arts Services known as the LCDC (Literary-Cultural } \\
\text { Development Center) }\end{array}$ & 4.39 & Strongly Agree \\
\hline $\begin{array}{l}\text { The students are properly screened as to their grades \& talents } \\
\text { before they can join the LCDC and are given the chance to } \\
\text { avail institutional scholarship. }\end{array}$ & 5.00 & Strongly Agree \\
\hline $\begin{array}{l}\text { The LCDC is developing students to become highly } \\
\text { competitive in any arts \& culture competition. }\end{array}$ & 4.31 & Strongly Agree \\
\hline $\begin{array}{l}\text { The LCDC is fully supported by the University in promoting } \\
\text { culture and arts activities. }\end{array}$ & 4.28 & Strongly Agree \\
\hline 5. Coaches and trainers are highly competent and qualified. & 4.37 & Strongly Agree \\
\hline Average Weighted Mean & $\mathbf{4 . 3 6}$ & Strongly Agree \\
\hline
\end{tabular}

The data above indicates that the student-respondents of NEUST San Isidro Campus were very satisfied with the culture and arts services of the campus and it has an average weighted mean of 4.36. Based on the CHED Memorandum Order No. 09, Series of 2013, the university must provide opportunities for the students to realize the importance of the culture and the arts. This is the door to promote the culture of the Philippines and make the students appreciate the value of preserving our culture [10]. The presence of the office is an important part of cultural education, which 
pushes the students to make a reflection in the culture of as well.

this country and builds respects on other countries' culture

\section{Assessment of the Respondents onFood Services}

Table.10: Assessment of Food Services

\begin{tabular}{|c|c|c|}
\hline Considerations & Weighted Mean & Verbal Description \\
\hline 1. There is a School Canteen located at the Campus. & 4.32 & Strongly Agree \\
\hline $\begin{array}{l}\text { 2. There is a Certificate to Operate/ sanitary permit } \\
\text { posted/displayed in a prominent area of the food outlet. }\end{array}$ & 4.36 & Strongly Agree \\
\hline $\begin{array}{l}\text { 3. There are enough food kiosks available which cater clean \& } \\
\text { nutritious food within the Campus. }\end{array}$ & 4.36 & Strongly Agree \\
\hline 4. Foods are properly labeled as to its name and price. & 4.36 & Strongly Agree \\
\hline 5. Canteen personneland helpers observed proper grooming. & 4.40 & Strongly Agree \\
\hline 6. There is a School Canteen located at the Campus. & 4.32 & Strongly Agree \\
\hline Average Weighted Mean & 4.36 & Strongly Agree \\
\hline
\end{tabular}

In the data above, it has been revealed that the students were very satisfied with the food services of the campus with an average weighted mean of 4.36. This only denotes that there is an available, adequate, safe and healthy food within the school premises or even to immediate vicinity around the campus. Their compliance is in accordance with the sanitation guidelines of the Department of Health with regards to food establishments [24].

\section{CONCLUSIONS AND RECOMMENDATIONS}

Majority of the enrollees in the campus took the courses being offered from the College of Information and Communications Technology and this department is a male-dominated department. From the results, Guidance and Counselling, Career and Placement, Student Activities, Student Publication and Student Development, Scholarship and Financial Assistance,Sports Development, Culture and the Arts, and Food Servicedelivered their programs and services very satisfactory which shows that they were able to comply with the enhanced guidelines and policies set by the Commis sion on Higher Education.

On the other hand, the Admission Services/Registrar's Services was rated satisfactory in the delivery of their servicesto the students which is an indicator that this area must be further improved.

Based on the findings, the following recommendations were formulated: The NEUST, San Isidro Campus should check the area that is not rated very satisfactory by the students to have a clearer picture of the lack of excellence in the delivery of the service. Furthermore, the NEUST as an institution which aim is to deliver excellent service must continue to evaluate their programs and services in all its existing colleges and campuses to assure that they are providing quality as sistance to their clienteles.

\section{REFERENCES}

[1] Malik, M., Danish, R. and Usman, A. (2011). The Impact of Service Quality on Students' Satisfaction in Higher Education Institutes of Punjab, University of Punjab, July 2011. Retrieved from: https://www.researchgate.net/publication/259042645

[2] Hasan, H., Ilias, A., Rahman, R. and Razak, M. (2008). Service Quality and Student Satis faction: A Case Study at Private Higher Education Institutions, International Business Research Vol. 1, No. 3. Retrieved from: https://pdfs .semantics cholar.org/cf60/c92a0e44c941cddea f50858965122ddc82d0.pdf

[3] Tia, N., Dwi, K., Imas, S., and Yunizar. (2016). The Achievement of Competitive Advantage through Quality of Service at High Schools in West Java Province, Indonesia. Intemational Joumal of Economics, Commerce, and Management, Vol. IV, Is sue 12,

[4] Audin, K. and Davy, J. (2003). University Quality of Life and Learning (UNiQoLL): An approach to Student Wellbeing, Satisfaction, and Institutional Change. Joumal of Further and Higher Education, 27(4) pp.365-382. Retrieved from: https://www.tandfonline.com/doi/abs/10.1080/030987703 2000128073

[5] Palacio, A. B., Meneses, G. D. and Perez, P. J. P. (2002).The configuration of the university image and its relationship with the satisfaction of students. Joumal of Educational Adminis tration, 40(5), 486-505.

[6] Pereda, M., Airey, D., and Bennett, M. (2007). Service Quality in Higher Education: The Experience of Overseas Students, Journal of Hospitality, Leisure, Sport and Tourism Education Vol.6, No.2, ISSN: 1473-8376. Retrieved from: 
https://www.researchgate.net/publication/30930614 Serv

ice Quality in Higher Education the experience of ov erseas students

[7] Subia, Gener S., Salangsang, Lily G. and Medrano, Hernina B.(2018). Attitude and performance in mathematics $\mathrm{I}$ of bachelor of elementary education students: A correlational analys is. American Scientific Research Joumal for Engineering, Technology, and Sciences (ASRJETS) (2018) Volume 39, No 1, pp 206 213

[8] Powell, R. (2006) Evaluation Research: An Overview. Library Trends, 55, 102-120. https://doi.org/10.1353/lib.2006.0050

[9] Subia, G. (2018) Comprehensible Technique in Solving Consecutive Number Problems in Algebra. Joumal of Applied Mathematics and Physics, 6, 447-457. doi: $10.4236 /$ jamp.2018.63041.

[10] Commission on Higher Education Official Site. (2013). Retrieved from: https://ched.gov.ph/cmo-9-s-2013/

[11] Mishra, S., Draus, P., Caputo, D., Leone, G., Kohun, F. and Repack, D. (2014). Gender Rationales in Selecting a Major in Information Technology at the Undergraduate Level of a University Program: A Focus Group Approach. Information Systems Education Journal (ISEDJ) Vol. 12 Issue 4, ISSN: 1545-679X. Retrieved from: https://files .eric.ed.gov/fulltext/EJ1140750.pdf

[12] Student Brands Prime. (2017). Top 5 Reasons to Study Information Technology. Retrieved from: https://www.studentbrands.co.za/employment/careerguidance/top-5-reasons-study-information-technology/

[13] Owino, Elizabeth Akinyi. (2015). Assessment of Service Delivery in Guidance and Counselling Units in Selected Secondary Schools in Eldoret Municipality, Kenya.Joumal of Education and Practice, ISSN 22221735, Vol.6, No.19. Retrieved from: https://files.eric.ed.gov/fulltext/EJ1079539.pdf

[14] Pecku, N. K. (1991). Introduction to Guidance for Training Colleges (2nd ed.). Ghana: Accra: University Press. Retrieved from: https://www.worldcat.org/title/introduction-to-guidancefor-training-colleges/oclc/29451334

[15] Ahrens, Luanne M. (1994). Satisfaction with College Outcomes and Career Services: A Study of Students Enrolled at Public 2-Year and 4-Year Institutions in the Midwest. Retrospective Theses and Dissertations. 10578. Retrieved from: https://lib.dr.iastate.edu/rtd/10578

[16] Mckay, Don Rosenberg. (2018). What Do College Career Services Offices Do? Retrieved from: https://www.thebalancecareers .com/what-do-collegecareer-services-offices-do-525477

[17] Sutherland, JJ. (2014). What is the Importance of a Student Publication? Retrieved from:
https://www.quora.com/What-is-the-importance-of-astudent-publication

[18] Giva Blog. (2015). Effects of Scholarships on Student Success. Retrieved from: https://www.givainc.com/blog/index.cfm/2015/1/23/Effe cts-of-Scholarships-on-Student-Success

[19] Cajucom, Rita L., Campos, Romeo B. and Mina, Jennilyn C. (2019). Appraisal of the Choice of College among Management and Business Technology Freshman Students. International Joumal of Advanced Engineering, Management, and Science (IJAEMS) Vol-5, Issue-1, ISSN: 2454-1311. Retrieved from: https://www.researchgate.net/publication/330919115 Ap praisal of the Choice of College among Management and Business Technology Freshman Students

[20] Soliven, Preciosa S. (2017). The School Registrar's Attempt to Provide Quality Service. Retrieved from: https://www.philstar.com/other-sections/education-andhome/2017/08/16/1729813/school-registrars-attemptprovide-quality-service

[21] DCU Sports and Wellbeing. (n.d.).Student Support \& Development. Retrieved from: https://www.dcu.ie/students/az/sports-development

[22] Ghildiyal R. Role of Sports in the Development of an Individual and Role of Psychology in Sports.Mens Sana Monogr 2015;13:165-170. Retrieved from: https://www.ncbi.nlm.nih.gov/pmc/articles/PMC4381313 1

[23] Garcia, Mary Grace G., and Subia, Gener, S. (2019). High School Athletes: Their Motivation, Study Habits, Self-discipline, and Academic Performance. International Joumal of Physical Education, Sports and Health 2019; 6(1): 86-90. Retrieved from: https://www.researchgate.net/profile/Gener Subia/public ation/330839121 High school athletes Their motivatio n study habits selfdiscipline and academic performance/links/5c5688b4a6 fdccd6b5ddeb6d/High-school-athletes-Theirmotivation-study-habits-self-discipline-and-academicperformance.pdf

[24] Department of Health Official Site. (2019). Retrieved from: https://www.doh.gov.ph/node/5731 